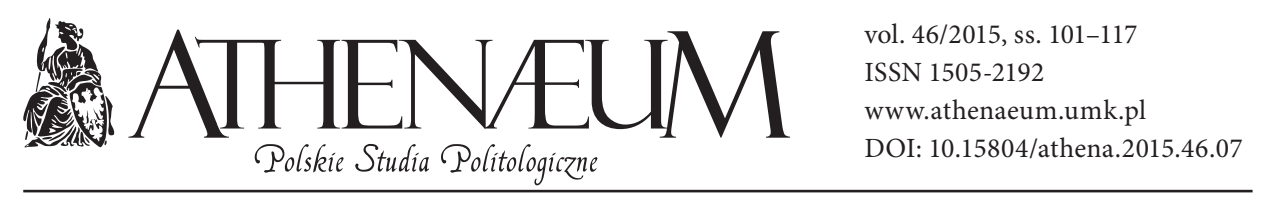

\title{
ABORYGENI AUSTRALIJSCY - ZATRACENI W CYWILIZACJI
}

\author{
Agnieszka Kandzia-Poździał*
}

ABORIGINAL AUSTRALIANS - LOST IN CIVILIZATION

\begin{abstract}
Aboriginal Australians last in the age of perdition. There has been 224 years since the day that Captain Arthur Phillip came to Australia with British convicts. Since then almost every day Aboriginal 'collide with civilization' and fight for surviving. All rules of tribal life had to be replaced by new ones. They had to wear clothes, live in houses of bricks, and work. All of this was completely different from the previous life. 'White civilization' that has brought the development into the Antipodes has also brought reasons of perdition. Among those: illnesses, which decimate Aboriginal clans, and alcohol, which destroys all residues of ancient Stone Age culture and causes many social problems. For several dozen years, Australian government has been trying to make up for Aboriginal wrong, but programs for improvement of their situation do not work. 'Civilization', in social evolutionists' opinion, should be the highest level of people's culture, for Aboriginal though it is some kind of abyss in which they cannot or they do not want to find a proper place for themselves.
\end{abstract}

\section{KEYWORDS}

Aboriginal, Australia, Indigenous People, civilization

* Uniwersytet Śląski w Katowicach, Instytut Nauk Politycznych i Dziennikarstwa. 
Wiele osób odwiedzających Australię w XXI wieku za całą pewnością napotkało na swojej drodze agresywnych, kłótliwych, brudnych i często pijanych Aborygenów, siedzących w parkach lub na chodnikach. Trudno dzisiaj uwierzyć, że to potomkowie jednej z najstarszych kultur świata. Niełatwo przejść obok i nie zadawać sobie pytania, co też stało się z tą kulturą, która choć nigdy nie osiągnęła wysokiego stopnia rozwoju, nie musiała jednak upaść aż tak nisko.

Warto podkreślić na początku, że słowo „aborygen” nie odnosi się jedynie do mieszkańców kontynentu australijskiego. Połączenie łacińskich słów ab i origo oznacza tych, którzy mieszkają (znajdują się) gdzieś „od początku”, tych, „którzy byli pierwsi”. Trudno znaleźć w literaturze uzasadnienia, dla którego pojęcie „aborygen” stało się w języku potocznym utożsamiane z pierwotnymi mieszkańcami Australii. W artykule tym będę naprzemiennie używać pojęć „tubylec”, "Aborygen” (pisanego dużą literą dla odróżnienia od aborygenów kanadyjskich czy amerykańskich ${ }^{1}$ ) oraz „pierwotny mieszkaniec Australii”.

Aborygeni przybyli do Australii ok. 40 tysięcy lat temu. Niektórzy badacze, m.in. jeden z najbardziej znanych historyków australijskich - Manning Clark twierdzą, że badania przeprowadzone przy wykorzystaniu niektórych metod ${ }^{2}$ potwierdzają, że pierwsi osadnicy mogli przybyć na kontynent już 50 tysięcy lat temu ${ }^{3}$. Z całą pewnością jednak przywędrowali z obszarów Azji Wschodniej i Południowej poprzez wyspy obecnej Papui i Nowej Gwinei. Poziom mórz był wtedy znacznie niższy niż obecnie, dlatego nawet bez rozbudowanych i trwałych łodzi mogli dość łatwo przemieścić się na inny ląd4

Duński profesor Eske Willerslev stawia jednak inną - niezwykle ciekawą tezę. Jego zdaniem „Aborygeni wywodzą się w prostej linii z najbardziej zamierzchłej

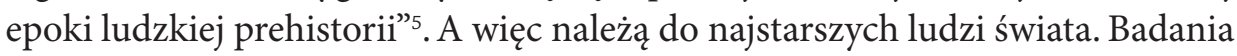
zakończone w 2010 roku doprowadziły do wniosku, że Aborygeni australijscy jako pierwsi wyodrębnili się z grupy Homo sapiens sapiens i 70 tysięcy lat temu rozpoczęli wędrówkę po świecie. To niezwykle ciekawe odkrycie sprawia, że patrzymy na Aborygenów nieco inaczej niż dotychczas, szczególnie zwracając przy tym uwagę na ich rozwój kulturowy.

Ich liczebność zmieniała się na przestrzeni dziejów. Wiadomo, że początkowo na stałe osiadło na kontynencie ok. 750 tysięcy ludzi. Trudne warunki

\footnotetext{
1 Także australijska poprawność polityczna nakazuje pisanie słowa „Aborygen” dużą literą.

2 Metoda datowania izotopem węgla ${ }^{14} \mathrm{C}$.

3 M. Clark, Historia Australii, Warszawa-Gdańsk 2004, s. 7.

4 P. Burchard, Australijczycy, Warszawa 1990, s. 10.

${ }^{5}$ W. Bęben, Aborygeni, pierwsi nomadzi. Życie i kultura, Gdańsk 2012, s. 458.
} 
klimatyczne i niedostępność źródeł wody spowodowały zmniejszenie tej liczby do ok. 300 tysięcy. Taka grupa przetrwała aż do chwili przybycia pierwszych brytyjskich statków w XVIII wieku. W kolejnych wiekach następowały dalsze zmiany liczebności tubylców. Walki z białymi, choroby nieznane dotąd na kontynencie oraz wypychanie Aborygenów (przez Europejczyków) na tereny, na których brakowało wody pitnej, spowodowały, że liczba pierwotnych mieszkańców zmalała do 60 tysięcy. Dalsza kolonizacja związana była z kolejnym spadkiem liczby Aborygenów - niektóre dane mówią nawet o 30 tysiącach. Badania Australijskiego Biura Statystycznego z 2006 roku wykazują, że liczba tubylców jest znacznie wyższa i wynosi ok. 517 tysięcy ludzi (czyli ok. 2,5\% populacji całej Australii) ${ }^{6}$. Dalsze prognozy odnośnie do tej liczby są pozytywne?

Etnografowie australijscy ustalili, że na kontynencie żyło niegdyś ok. 600 plemion tubylczych. Były one zróżnicowane pod względem liczebności, języka (stworzono ponad 200 systemów językowych i tylko sąsiadujące ze sobą plemiona potrafiły się porozumiewać, niektóre klany wykształciły w tym celu język migowy) oraz zaawansowania w rozwoju cywilizacyjnym (najbardziej rozwinięte były plemiona północne i północno-wschodnie). W momencie gdy James Cook w roku 1770 rozpoczął erę kolonizacji na Antypodach, zamieszkiwali północne części kontynentu (okolice dzisiejszego Darwin oraz półwysep York), wybrzeże wschodnie - niemal na całej jego długości oraz wybrzeże zachodnie. Niewielkie plemiona znajdowały się w centrum kontynentu, ale ze względu na niesprzyjający klimat nie było ich tam wiele. Znaczne, choć nie największe, zagęszczenie ludności pierwotnej występowało na obszarach, które dzisiaj znajdują się w granicach wschodnich stanów Nowa Południowa Walia i Queensland.

Warto jednak podkreślić, że Aborygeni byli ludem koczowniczym, opuszczali jeden obszar, by przenieść się w poszukiwaniu jedzenia i źródeł wody (czasem nawet co kilka dni), dlatego dokładne ustalenie miejsca ich pobytu jest niemożliwe.

Podstawowym zajęciem tubylców było polowanie, zbieractwo i na terenach nadmorskich rybołówstwo. Nie rozwinęło się jednak ono w wyraźny sposób, ponieważ wody Australii bogate w rekiny stanowiły niemałe zagrożenie dla

${ }^{6}$ Experimental Estimates and Projections, Aboriginal and Torres Strait Islander Australians, 1991 to 2021, Australian Bureau of Statistics, http://www.abs.gov.au/ausstats/abs@.nsf/Products/946D4BC28DB92E1BCA25762A001CBF38?opendocument, odczyt z dn. 10.02.2014.

7 Australijskie Biuro Statystyczne za indigenous - tubylców, miejscowych, uznaje nie tylko Aborygenów australijskich, ale także potomków mieszkańców Wysp Cieśniny Torresa (Torres Strait Istanders). Podkreśla się na każdym kroku różnorodność występującą pomiędzy tymi grupami. 

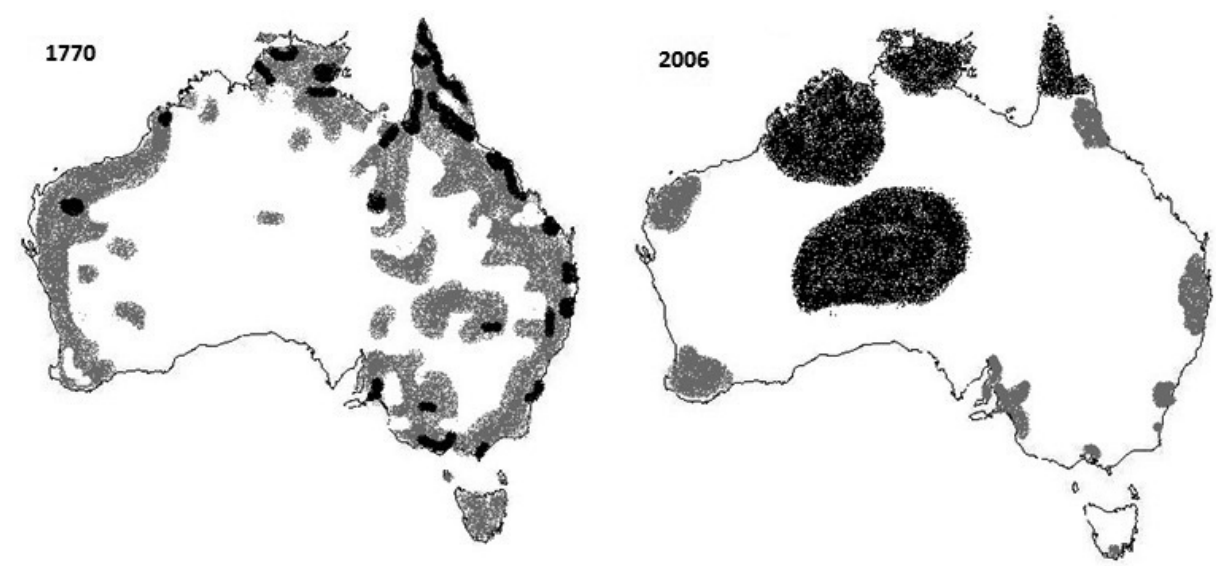

Rysunek 1: Obszary zamieszkane przez Aborygenów australijskich w XVIII i XXI wieku. Kolorem czarnym oznaczono tereny, gdzie Aborygeni występowali i występują najliczniej.

Źródło: Opracowanie własne na podstawie danych Australian Bureau of Statistics.

członków plemienia. Polowaniem, głównie na kangury i ptaki, zajmowali się mężczyźni i chłopcy, którzy przeszli rytuał inicjacji. Kobiety i dziewczęta zaopatrywały plemię w owoce, pędy oraz owady nadające się do przygotowania posiłku. Upolowany kangur był sukcesem całego plemienia, a nie jednej tylko rodziny. Wspólne były także ziemia, woda i niewielki dobytek plemienny. Pod względem rozwoju technicznego Aborygeni australijscy zatrzymali się na etapie prymitywnej epoki kamienia. Wynikać może to z dwóch przyczyn - skrajnie od siebie odmiennych. Wspomniany już M. Clark uważa, że powodem takiego stanu rzeczy był brak zbóż oraz zwierząt, które nadawałyby się do hodowli. Niemałe znaczenie przypisuje on również aborygeńskim wierzeniom ${ }^{8}$. Z kolei polski etnograf Przemysław Burchard jest zdania, że Aborygeni pozostali na niskim stopniu rozwoju, ponieważ nie istniała konieczność zmiany takiego stanu rzeczy. „Przyczyną wynalazków - pisze autor - jest bieda. Tubylcy biedy z pewnością nie odczuwali, ponieważ idealny podział terenów i doskonała ochrona zasobów przyrodniczych [utrzymywana dzięki przenoszeniu się z miejsca na miejsce A.K.] pozwalały żyć w dobrych - jak na ten szczebel kultury - warunkach" 9

\footnotetext{
${ }^{8}$ M. Clark, op.cit., s. 8.

9 P. Burchard, op.cit., s. 15.
} 
Nie należało zmieniać więc zasad ustalonych w plemieniu od tysięcy lat. To przyzwyczajenie do warunków życia oraz niechęć do wprowadzania zmian stały się istotnymi powodami, dla których zetknięcie z białym człowiekiem było doświadczeniem tragicznym w skutkach.

Nie tylko warunki klimatyczne miały wpływ na osłabienie postępu. Aborygeni nie spotykali się z zagrożeniem zewnętrznym. O ile można wskazać na walki plemienne (mające raczej charakter bijatyk o terytorium), to nie występowały przez dziesiątki tysięcy lat konflikty z przedstawicielami innych kultur czy cywilizacji. Nie znaczy to, że Aborygeni nie spotykali obcych. Na północy rozwinęli kontakty z Chińczykami przypływającymi w rejony półwyspu York na połowy trepangu. Kontakty te były jednak przyjazne. Niepotrzebne stało się więc tworzenie wyspecjalizowanej broni czy budowanie twierdz obronnych. Aborygeni nie budowali nawet domów. Najczęściej spali pod gołym niebem (w chłodne dni rozpalali nocne ogniska) lub w prowizorycznych szałasach. Ciągła wędrówka nie pozwalała na budowanie trwalszych osad, cały dobytek bowiem co kilka dni przenoszony był w inne miejsce. Nie budowali przy tym żadnych środków transportu.

Aborygeni, mimo iż nigdy nie stworzyli pisma, pozostawili trwały ślad w kulturze i sztuce. Bardzo rozbudowany i zróżnicowany system wierzeń był przekazywany ustnie z pokolenia na pokolenie. Matki opowiadały swym dzieciom bajki o początkach świata i pierwszych ludziach żyjących na Ziemi. Niezwykłe opowieści tzw. „Czasu Snu” rządziły się tymi samymi mechanizmami, co europejskie opowieści ludowe. Nie tylko jednak legendy i mity pozostały po startej kulturze. Na wielu skałach na całym kontynencie można obserwować różnorodne malowidła skalne. „Dokumentowano” opowieści „Czasu Snu”, ale także codzienne życie. Malowanie skał z użyciem głównie czterech kolorów (białego, żółtego, czerwonego i czarnego) służyło przekazywaniu myśli bóstwom, duchom przodków i członkom własnego plemienia. Zaawansowanie i dopracowanie tych dzieł, a także ich tematyka różniły się w zależności od miejsca. Na północy kraju są bardziej zaawansowane pod względem techniki i wzornictwa, w centrum kontynentu najbardziej skromne. Aborygeni rozpowszechnili też zdobnictwo przedmiotów użytkowych. Popularne było również zdobienie ciała, związane nie tylko $\mathrm{z}$ ważnymi plemiennymi uroczystościami. Warto już tym miejscu podkreślić, że mimo iż wiele elementów charakteryzujących Aborygenów zostało zniszczonych na zawsze, to sztuka - głównie malarstwo - przetrwały i są jedną z australijskich wizytówek. Malarstwo kropkowe, które dla potomków Aborygenów jest jedynie specyficznym obrazem świata, dla ludzi „cywilizowanych” 
sztuką wartą setki tysięcy dolarów. Tubylcy stworzyli też jeden z najstarszych instrumentów świata didgeridoo (zwany w niektórych plemionach yiraki, yiraga, magu, kanbi). Muzyka wydobywająca się z tej gałęzi drzewa powodowała, że słuchający wpadali w rodzaj transu - tym samym melodia stawała się pomostem między ludźmi a bóstwami. Pieśni, które najchętniej wykonywano podczas uroczystości plemiennych, uczono się od innych członków plemienia - najczęściej matek, starszych dzieci lub rady starców. Znaczenie rytuałów wykraczało poza ich funkcję społeczną. Przygotowaniu wszelkich obrządków i uroczystości poświęcano niezwykle wiele czasu ${ }^{10}$. Nie ma tu miejsca na szczegółowe opisywanie obrzędowości tubylców australijskich, ale te właśnie obyczaje, rytuały, kultywowanie tradycji są podstawą przetrwania kultur. Dzięki temu pierwotni mieszkańcy nie pozwalają o sobie zapomnieć, choć ich teraźniejszość i przyszłość nie maluje się w różowych barwach.

Po tym krótkim wstępie warto powrócić do zagadnienia głównego. Czy Aborygeni australijscy zatracili się w cywilizacji? Cywilizacja, o której mowa w tytule, doczekała się wielu interpretacji. Może być traktowana jako synonim kultury lub czasem jako inny - specyficzny rodzaj kultury lub jako sfera materialna w przeciwieństwie do sfery duchowej ${ }^{11}$. Dla mnie najważniejsza będzie jednak ta prezentowana przez wielu badaczy, głównie ewolucjonistów, a zakładająca, że cywilizacja jest postępowym, przyszłościowym, raczej pozytywnym etapem rozwoju kultury ludzkiej. W tym nurcie Edward Burnett Tylor mówił o cywilizacji w kontekście wiedzy, wiary, obyczajów, ale też stworzonego przez ludzi prawa $^{12}$. Nie mówi się więc jedynie o abstrakcyjnym wymiarze cywilizacji, ale o jej mnogości w wymiarze społecznym.

Najbardziej klasycznego podziału dokonał w swej książce Ancient society or researches in the lines of human progress from savagery through barbarism to civilization Lewis Henry Morgan (choć zaczerpnął swoje kategorie z pracy wcześniejszego badacza - Adama Fergusona ${ }^{13}$ ). Wyróżnił trzy fazy rozwoju ludzkości - etap dzikości, barbarzyństwa i cywilizacji. Ten ostatni właśnie traktował

10 J. Rickard, Australia. Historia kultury, Wrocław-Warszawa-Kraków 1994, s. 18.

${ }_{11}$ M. Golka, Cywilizacja, Europa, globalizacja, Poznań 1999, s. 12 i nast.

12 W. Tatarkiewicz, Parerga, Warszawa 1978, s. 75.

13 Adam Ferguson nawiązywał w swojej pracy Essay do Adama Smitha i jego czterofazowego modelu rozwoju społeczno-ekonomicznego ludzkości. A. Ferguson skupiał się na strukturze społecznej i ustroju politycznym. Wskazywał, że okres dzikości charakteryzuje się polowaniem i zbieractwem, barbarzyństwo to czas pasterstwa i rolnictwa, a cywilizacja jest okresem handlu. Zob.: J. Szacki, Historia myśli socjologicznej, Warszawa 2002, s. 115. 
jako najwyższe stadium rozwoju ogólnie rozumianej kultury, dla którego charakterystyczne jest powstanie alfabetu fonetycznego i pisma. Podstawą ewolucji społecznej zdaniem L. Morgana było przechodzenie od własności wspólnej (tzw. komunizmu pierwotnego) do własności prywatnej ${ }^{14}$.

Zdaniem Gerarda Delantego „cywilizowanymi” byli Europejczycy, w szczególności ci z zachodniej części kontynentu. „Niecywilizowanymi” zaś przedstawiciele kultur nieeuropejskich. Tak skrajny europocentryzm dawał podstawy do rozszerzania się imperializmu na tereny niecywilizowane w celu krzewienia europejskiej ideologii, prawa i moralności ${ }^{15}$. Władysław Tatarkiewicz, pisząc o cywilizacji (stanie obiektywnym) w opozycji do pojęcia kultury (stanu subiektywnego), podkreślał: „niech cywilizacja oznacza to wszystko, co ludzkość stworzyła, dodała do natury dla ułatwienia i ulepszenia życia i co wielu ludziom jest wspólne [...] cywilizacja czyni, że świat dzisiejszy jest różny od pierwotnego, a kultura, że ludzie dzisiejsi są od pierwotnych różni” ${ }^{16}$. Badacz ten zwracał uwagę, że mamy do czynienia z różnymi cywilizacjami o różnym stopniu zaawansowania, zawsze jednak mówimy o pewnej „nadbudowie” nad naturalną i prymitywną egzystencją ludzkiej jednostki ${ }^{17}$. Z cywilizacją w sensie postępu technicznego i ekonomicznego mamy do czynienia w publikacji Józefa Bańki Cywilizacja - obawy i nadzieje, w której autor zadaje ważne z punktu widzenia mojej pracy pytanie: „Czy człowiek może się przystosować psychicznie do postępującej w szybkim tempie cywilizacji technicznej?"18. Proces przechodzenia do najwyższych faz rozwoju kulturowego i przystosowanie do nowej cywilizacji powinny odbywać się w sposób naturalny dla wszystkich społeczności. Wskazywać to bowiem będzie na przyśpieszenia tempa ewolucji, „które ma zachodzić jednak do pewnej tylko granicy, jaką są zdolności przystosowawcze"19.

Nagłe i nieoczekiwane zetknięcie się Aborygenów z nowymi zasadami życia we wspólnocie, z ludźmi o znacznie wyższym stopniu rozwoju cywilizacyjnego spowodowało, że ich kultura, całe plemiona i poszczególne jednostki wkroczyły w „epokę zatracenia”. Idąc tropem J. Bańki, przyzwyczajenie do nowego życia stało się tylko dla niektórych procesem, efektywnym, choć długotrwałym. Dla

14 J. Szacki, Historia myśli socjologicznej, Warszawa 2002, s. 308-309.

15 G. Delanty, Odkrywanie Europy: idea, tożsamość, rzeczywistość, Warszawa 1999, s. 124-126.

16 W. Tatarkiewicz, op.cit., s. 76.

17 Ibidem, s. 77.

18 J. Bańka, Cywilizacja - obawy i nadzieje, Warszawa 1979, s. 8.

19 M. Golka, op.cit., s. 17. 
większości jednak proces ten trwa nadal i trudno wskazać moment, w którym może się zakończyć.

Niemal od początku kontakty Aborygenów z cywilizowanymi białymi nie należały do przyjaznych. Jednak warto podkreślić, że nie ma żadnych dokumentów na to, że Brytyjczycy zaplanowali eksterminację ludności tubylczej i że mieli zamiar wyprzeć Aborygenów z ich terytoriów. Jak podkreśla P. Burchard, wszystko działo się przez „eskalację wzajemnego niezrozumienia, przez łańcuch aktów krzywd, odwetu, zemsty" ${ }^{20}$. Biali zajmowali tereny, które Aborygeni opuścili w poszukiwaniu jedzenia. Europejczycy przyzwyczajeni do aktów własności terenów uznali, że ludy koczownicze nie posiadają własnych obszarów. Tak zresztą zrodziła się zasada terra nullius - ziemia niczyja, obszar niezamieszkany, a więc nienależący do nikogo - obowiązująca podczas zasiedlania kolonizowanych terytoriów ${ }^{21}$. „Biali osadnicy, ogradzając pastwiska i tępiąc kangury, niszczyli - sami o tym nie wiedząc - łowieckie tereny tubylców. Gdy zaś tubylcom zabrakło kangurów, zabijali owce lub krowy. Dla tubylca owca była kangurem, który nie ucieka, łatwo go więc upolować. Nie mieli wyobrażenia o własności w stosunku do zwierząt. Biali znowu nie mogli pojąć, że ktoś nie odróżnia zwierzęcia hodowanego, prywatnego od dzikiego, niczyjego"22. Tubylcy szybko zorientowali się, że nowi osadnicy nie przypłynęli tu na chwilę i nie zamierzają opuścić terenów, które zajęli. Problemem było nie tylko naruszanie terytoriów łowieckich, ale także porywanie i gwałcenie czarnoskórych kobiet ${ }^{23}$. Miejscowi napadali więc i mordowali brytyjskich myśliwych, żołnierzy i skazańców ${ }^{24}$.

20 P. Burchard, op.cit., s. 82.

${ }^{21}$ Dopiero w 1992 roku australijski Sąd Najwyższy unieważnił obowiązującą od ponad 200 lat zasadę terra nullius. A w roku kolejnym przyjęto Ustawę o prawie pierwszych mieszkańców (Native Title Act) określającą prawa własności Aborygenów australijskich. Otrzymali oni wówczas prawo do ziemi, która ma dla nich znaczenie religijne.

${ }^{22}$ P. Burchard, op.cit., s. 98.

${ }^{23} \mathrm{~W}$ plemionach aborygeńskich starszy mężczyzna miał prawo do posiadania większej ilości młodych kobiet. Młodsi zaś mężczyźni mieli zwykle jedną żonę w starszym wieku. Wiek i tym samym posiadanie kobiet świadczyło więc o wysokiej pozycji w danym plemieniu. Uprowadzanie młodych kobiet przez żołnierzy brytyjskich stwarzało więc realne zagrożenie dla poszanowania autorytetów plemiennych budowanych od tysięcy lat.

24 Pierwsza Flota (First Fleet), która przypłynęła do Australii w 1788 roku, składała się z 1044 osób. Na 11 statkach pod dowództwem kapitana Arthura Phillipa znalazło się 696 więźniów (wywiezionych do Australii, która w wyniku problemów w Stanach Zjednoczonych miała stać się nową kolonią karną Wielkiej Brytanii), 212 żołnierzy (w tym oficerów, mających trzymać pieczę nad skazańcami) wraz z rodzinami (45 osób), 81 wolnych osadników (ludzi, którzy chcieli sprawdzić możliwości stałego osiedlenia na nowym lądzie, oraz badaczy i naukowców, m.in. biologów, zoologów), 
W odwecie Brytyjczycy rozstrzeliwali Aborygenów bez względu na to, czy byli winni poprzednich przestępstw, czy nie. Przed przybyciem białych plemiona Aborygenów były rozproszone i nie potrzebowały koncentracji sił. W obliczu zagrożenia wódz Pemulway zjednoczył pod sobą kilka plemion koczujących w okolicach Port Jackson (dzisiejszego Sydney). Walki odbywały się regularnie, bardzo często stroną zwycięską byli tubylcy ${ }^{25}$. Z czasem jednak ich możliwości były coraz bardziej ograniczone. Skrajnym przykładem mogą być tutaj plemiona zamieszkujące Ziemię Van Diemena (obecną Tasmanię). Zakładanie miast najpierw w Risdon Cove (w okolicach dzisiejszego Hobart), a później nad rzeką Tamar (dzisiaj Launceston) spowodowało, że na terenach dotąd odizolowanych dochodziło, nieraz przez zupełny przypadek, do masakry ludności tubylczej (największa miała miejsce w Risdon w 1804 roku) ${ }^{26}$. Do lat trzydziestych XIX wieku w wyniku tzw. „,czarnej wojny” wybito prawie wszystkich pierwotnych mieszkańców tej wyspy. Resztą przesiedlono na Wyspy Flindersa. Przypuszcza się, że ostatnia czystej krwi Aborygenka tasmańska - Truganini - zmarła w 1876 roku ${ }^{27}$.

Nie tylko jednak mordowanie tubylców powodowało, że nienawiść do białych osadników rosła. Czymś, co pozostawiło głęboką rysę w stosunkach Aborygenów z Europejczykami, jest asymilacja, określana po latach mianem „skradzionego pokolenia" (stolen generation). W roku 1869 w stanie Victoria uchwalono Ustawę o ochronie Aborygenów. Określono wówczas, gdzie tubylcy mogą żyć i pracować oraz z kim zawierać małżeństwa ${ }^{28}$. Rozpoczął się wówczas proces ograniczania ich wolności. Rządy stanowe, a później rząd federalny rozpoczęły prowadzenie wobec tubylców polityki intensywnej asymilacji. Najprostszym sposobem, by przyzwyczaić Aborygenów do życia w społeczeństwie kolonialnym oraz nie dopuścić do rozprzestrzeniania się wymierającej (ich zdaniem) kultury, było odseparowanie

a także 10 urzędników administracji państwowej (których zadaniem była organizacja i zarządzanie kolonią w pierwszym okresie jej funkcjonowania). Zob. Australian Discovery and Colonisation, Empire (Sydney, NSW: 1850-1875) 1865, s. 8, National Library of Australia: http://trove.nla.gov.au/ndp/del/ article/60569425, odczyt z dn. 10.02.2014.

${ }^{25}$ P. Burchard, op.cit., s. 81.

26 Tubylcy, którzy prawdopodobnie cała grupą polowali na kangura, zostali przez żołnierzy brytyjskich rozpoznani jako wrogowie atakujący wojska i zastrzeleni - zginęło wówczas 50 Aborygenów.

27 Australian Dictionary of Biography, Trugernanner (Truganini) (1812-1876) http://adb.anu.edu. au/biography/trugernanner-truganini-4752, odczyt z dn. 10.02.2014.

28 Aboriginal Protection Act, $11^{\text {th }}$ November 1869, http://foundingdocs.gov.au/resources/transcripts/vic7i_doc_1869.pdf, odczyt z dn. 10.02.2014. 
tubylców od grupy plemiennej i przekazanie społeczeństwu anglosaskiemu. Dzieci rodzin aborygeńskich (w szczególności te o jaśniejszej karnacji) zabierano więc $\mathrm{z}$ rodzinnych terytoriów i przenoszono tysiące kilometrów w inną część kontynentu. Robiono to zarówno bez zgody, jak i z wymuszonym poparciem rodziców ${ }^{29}$. Tam były adoptowane przez białych rodziców lub umieszczane w internatach. Także kościoły protestanckie i katolickie przejęły rolę nauczycieli i opiekunów dzieci do 16 lub 21 roku życia. U podstaw usuwania dzieci z ich naturalnego środowiska leżała opieka nad ich rozwojem i przyszłością oraz zapobieżenie niedożywieniu i zaniedbaniu. W raporcie sporządzonym w 1997 roku przez Ronalda Wilsona poświęconym skradzionemu pokoleniu przeczytamy, że być może nawet co trzecie aborygeńskie dziecko zostało zabrane rodzinie i wywiezione ${ }^{30}$. Dokładna liczba dzieci odseparowanych od matek nie jest jednak znana. Proces ten do dzisiaj wzbudza wielkie emocje. Oficjalne przeprosiny wystosowane w 2008 roku przez premiera Kevina Ruda wobec społeczności aborygeńskiej przyniosły jedynie chwilowe ukojenie. Trudno też zrozumieć fakt, że dopiero w 1967 roku, w wyniku ogólnonarodowego referendum, Australijczycy zadecydowali o przyznaniu Aborygenom pełni praw obywatelskich. Do tego czasu funkcjonowali w ramach Księgi fauny i flory Nowej Południowej Walii (Flora and Fauna Act of NSW) ${ }^{31}$.

Zderzenie dwóch tak skrajnie różnych kultur dla tej słabszej okazało się tragiczne w skutkach. Do dzisiaj w społeczności Aborygenów rodzą się problemy, których początku możemy szukać jeszcze w czasach kolonizacji.

Brytyjczycy wraz z „cywilizacją materialną” przywieźli z Europy także coś, przed czym nie można było się bronić - choroby. Organizmy nieprzystosowane do bakterii i infekcji, z którymi do tej pory nigdy się nie spotkały, stawały się bezbronne. Aborygeni umierali na odrę, ospę, gruźlicę i choroby weneryczne. Przypisując je działaniu złych duchów, wypędzali chorych z plemion. Zarazy wielokrotnie dziesiątkowały jednak tubylców. Dzisiaj największą plagą oprócz problemów

${ }^{29}$ W Australii Zachodniej dzieci aborygeńskie zaraz po urodzeniu stawały się własnością państwa, dlatego zgoda rodziców na ich wywiezienie nie była wymagana. W pozostałych miejscach Aborygeni, którzy nie znali języka angielskiego „wyrażali zgody” na wywóz dzieci, nie rozumiejąc konsekwencji.

30 P. Howson, The Stolen Generations. True Believers Take One Step Back, „National Observer” 2001, no. 49, http://www.nationalobserver.net/2001_winter_legal.html, odczyt z dn. 10.02.2014.

31 J. Pearlman, J. Gibson, When I Was Fauna: Citizen's Rallying Call, „The Sydney Morning Herald” 23.05.2007, http://www.smh.com.au/news/national/when-i-was-fauna-citizens-rallying-call/ 2007/05/22/1179601412706.html, odczyt z dn. 10.02.2014. 
alkoholowych, o których wspomnę nieco później, są właśnie choroby weneryczne. Na rzeżączkę w 2010 roku chorowało 804 na 100000 Aborygenów ${ }^{32}$. Do tego dochodzą też inne choroby, jak: syfilis, chlamydia czy AIDS. Choć ośrodki medyczne finansowane przez rząd australijski prowadzą szeroko zakrojone badania ludności aborygeńskiej, to wiele przypadków pozostaje wciąż nie zdiagnozowanych. Badania przeprowadzone przez naukowców z Instytutu Kirby Uniwersytetu w Nowej Południowej Walii pokazują, że chorują głównie ludzie młodzi, od 15 do 29 roku życia. Najwięcej przypadków zachorowań odnotowywanych jest na obszarach znacznie oddalonych od ośrodków miejskich ${ }^{33}$. Australijska Komisja ds. Aborygenów i Mieszkańców Wysp Cieśniny Torresa (ATSIC), działająca w latach 1990-2004, wydała kilka miliardów dolarów na rozwiązywanie problemów zdrowotnych w aborygeńskich wioskach. Aborygeni dożywają średnio wieku 50 lat, a więc żyją o ok. 17 lat krócej niż pozostali Australijczycy ${ }^{34}$.

Duchowni protestanccy przez wiele lat wierzyli, że potrafią wydobyć Aborygenów „ze stanu barbarzyństwa do stanu cywilizacji” ${ }^{35}$. Wszelkie próby przynosiły jednak marne efekty. Aborygeni nie godzili się bowiem na zaproponowane przez Europejczyków nowe zasady życia. Tubylcy, chodzący do tej pory nago lub prawie nago, musieli się ubrać. To z kolei krępowało ich ruchy i zabierało swobodę. Biali próbowali przekupić miejscowych ubraniami, ozdobami, nowymi barwnymi tkaninami, jednak ci zwykle porzucali je w najbliższym lesie ${ }^{36}$. W ubraniu nie można było wykonywać tradycyjnych wzorów na ciele. Aborygeni i dzisiaj nie przywiązują uwagi do strojów - najczęściej są one brudne i wybrakowane, a mężczyźni i chłopcy bardzo chętnie pozbywają się górnej części stroju.

W XIX wieku tych, którzy byli zdrowi, silni i nie wykazywali oporów przed nawiązywaniem kontaktów z białymi, zatrudniano na wielkich farmach przy hodowli bydła i owiec. To także rodziło problemy. Tubylcy, którzy kontaktowali się z Europejczykami, byli często przepędzani lub nawet zabijani przez swoich towarzyszy z grupy plemiennej. Miejscowym nie płacono, a za wykonanie pracy

32 Wśród reszty populacji australijskiej (non-indigenous people) wskaźnik ten wynosi 30 na 100 000. Zob. Bloodborne Viral and Sexually Transmitted Infections in Aboriginal and Torres Strait Islander People: Surveillance and Evaluation Report 2011, Kirby Institute, University of New South Wales, http://www.med.unsw.edu.au/NCHECRweb.nsf/resources/2011/\$file/KIRBY_ATSIP2011. pdf, odczyt z dn. 10.02.2014, s. 9.

33 Bloodborne viral..., op.cit., s. 14-16, 19-21, 23-25.

${ }^{34}$ M. Clark, op.cit., s. 248.

${ }^{35}$ Ibidem, s. 60.

36 P. Burchard, op.cit., s. 99. 
najczęściej otrzymywali pożywienie lub alkohol. Praca dla Aborygena nigdy nie była jednak obowiązkiem, dlatego bywało, że po kilku dniach już nigdy więcej nie pojawiali się na farmach. Polityka „białej Australii” (White Australia Policy), zapoczątkowana w pierwszych latach XX wieku, a trwająca do lat siedemdziesiątych, odnosiła się nie tylko do imigrantów, ale także do Aborygenów. Nie zatrudniano ich na farmach, nie mieli prawa stać się członkami Unii Robotników Australijskich (Australian Workers' Union). Uchwalony na początku XX wieku Akt o rentach i emeryturach obejmował jedynie białych mieszkańców kontynentu pochodzenia europejskiego.

Także i dzisiaj zatrudnienie Aborygena jest dla australijskiej firmy nie lada wyzwaniem. Według raportu australijskiej Komisji Praw Człowieka „ośmiu Aborygenów na dziesięciu nie ma dostępu do rynku pracy z powodu analfabetyzmu, alkoholizmu i poważnych urazów psychicznych. W niektórych wiejskich obszarach 70\% dzieci nie chodzi do szkoły"37. Część Aborygenów pracuje przy hodowli zwierząt lub uprawie zbóż owoców, są sprzątaczami lub pomocnikami przy pracach fizycznych w magazynach. Dodatkowo objęci są jednak opieką rządową w rezerwatach lub ośrodkach misyjnych. Bezrobotni otrzymują specjalne zasiłki. Sytuacja zatrudnienia poprawia się jednak. Sześć lat wcześniej wskaźnik ten był na poziomie $46 \%^{38}$. Obowiązkiem zakładów pracy jest prowadzenie szczególnej polityki rekrutacyjnej uwzględniającej różnice kulturowe. W firmach takich pracują przeszkoleni menagerowie - przygotowani do pracy z Aborygenami, a dla pracowników organizowane są kursy języka angielskiego i wypłacane specjalne premie miesięczne. Obowiązują też rygorystyczne przepisy antydyskryminacyjne ${ }^{39}$.

Stosunkowo częstym zjawiskiem wśród Aborygenów jest absencja w pracy. Nie jest rzadkością, że Aborygeni po kilku dniach pracy nie pojawiają się w niej ponownie. Głównie wynika to ze zobowiązań rodzinnych i klanowych. Zdarza się, że gdy w wioskach tubylczych umiera któryś z członków plemienia, cała jego rodzina porzuca dotychczasowe zajęcia, by przybyć do wioski lub rezerwatu

37 Y. Mamou, In Australia: Atonement through Employment, „Le Monde”, 16.07.2010, http://www. sodexo.com/en/Images/572138_20100716_Sodexo-Autralia-diversity.pdf, odczyt z dn. 10.02.2014.

${ }^{38}$ Labour Force Status, National Aboriginal and Torres Strait Islander Social Survey 2008, Australian Bureau of Statistics, http://abs.gov.au/AUSSTATS/abs@.nsf/Latestproducts/4714.0Main\%20 Features92008 opendocument $\&$ tabname $=$ Summary $\&$ prodno $=4714.0 \&$ issue $=2008 \&$ num $=\& v i e w=$, odczyt z dn. 10.02.2014.

39 B.H. Hunter, A.E. Hawke, Industrial Relations in Workplaces Employing Indigenous Australians, http://caepr.anu.edu.au/sites/default/files/Publications/DP/2000_DP200.pdf, odczyt z dn. 10.02.2014. 
i wziąć udział w ceremoniach żałobnych. Bywa, że trwają one do kilku tygodni, a o ich zakończeniu, jak przed wiekami, decydują klanowi starcy ${ }^{40}$. To powoduje, że pracownicy pochodzenia aborygeńskiego są pracownikami niepewnymi i w kraju, w którym poszanowanie dla pracy jest jedną z najwyższych wartości, stają się nieprzydatni. Ci, którzy o zatrudnienie dbają, mogą zarabiać spore pieniądze. Jednak także finanse wśród potomków pierwotnych mieszkańców są kwestią trudną do rozwiązania. Przed przybyciem kolonizatorów większość aborygeńskich plemion posługiwała się ograniczonym systemem liczbowym, składającym się jedynie z „cyfr”: „zero”, „jeden”, „dwa” i „wiele”. Niektóre tylko plemiona potrafily liczyć do „pięciu”. Obcowanie z pieniędzmi o różnej wartości stanowiło więc początkowo nie lada trudności. Również dzisiaj otrzymywane pensje nie stanowią własności prywatnej i w zdecydowanej większości są dzielone pomiędzy wszystkich członków plemienia. Osobom niepracującym, jak wspomniano, wypłacane są zasiłki - nieraz tak duże, że pracować po prostu się nie opłaca. Zapomogi te są jednak obcinane - głównie po to, by były wydawane jedynie na żywność i ubrania, a nie alkohol, papierosy i narkotyki.

Z każdym rokiem polepsza się sytuacja w sferze edukacji. W badaniach z 2008 roku odnotowano, że 95\% badanych dzieci pierwotnych mieszkańców Australii uczęszczało (w miarę) regularnie do szkoły. Wpływa to zdecydowanie na poziom wykształcenia młodych Aborygenów. Na wykresie numer 1 pokazano zmiany w poziomie wykształcenia na przestrzeni 14 lat. Widać wyraźnie, że wzrasta odsetek osób, które ukończyły obowiązkowe 10 klas szkoły ${ }^{41}$. Coraz więcej też uczniów kontynuuje naukę i przystępuje do matury państwowej. Nieznacznie, ale wzrasta liczba tubylców, którzy sięgają po wyższe wykształcenie na poziomie licencjatu - zwykle, jak wynika z badań, studia podejmują jednak po niewielkiej przerwie w zdobywaniu wiedzy, a więc najczęściej w wieku 30-50 lat. Nie zmienia to jednak faktu, że najwięcej młodych ludzi pochodzenia aborygeńskiego kończy edukację w wieku 15 lat.

W latach 20. XX wieku gubernator Ziemi Van Diemena - sir George Arthur wierzył, że tubylców da się ucywilizować, jednak nie przypuszczał, że barierą na tej drodze staną się sami Brytyjczycy. Kiedy w pobliżu Hobart Arthur nakazał

40 Ibidem.

41 System edukacji w Australii zobowiązuje uczniów do nauki przez 10 lat (do 15-16 roku życia), przystąpienie do matury może nastąpić jednak dopiero po ukończeniu 12 lat nauki (do 17-19 roku życia). Kolejnym etapem mogą być studia wyższe, które w zależności od kierunku studiów trwają 3 , 4 lub 6 lat, i po ich ukończeniu zyskuje się tytuł licencjata. Możliwe jest kontynuowanie nauki na studiach wyższych (do poziomu magistra i doktora). 


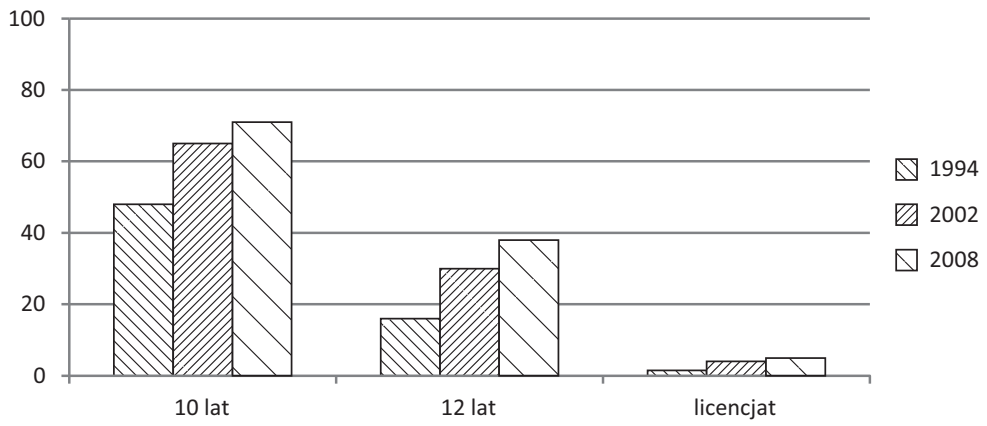

Wykres 1: Zmiana poziomu wykształcenia wśród Aborygenów i mieszkańców Wysp Cieśniny Torresa w latach 1994-2008 (dane w proc.)

Źródło: Education and Indigenous Wellbeing, Australian Social Trends 2011, Australian Bureau of Statistics, http://www.abs.gov.au/AUSSTATS/abs@.nsf/Lookup/4102.0Main+Features50Mar+2011\#endnote5, odczyt z dn. 10.02.2014.

odzianie i nakarmienie Aborygenów oraz zapewnił ochronę przez zniewagami, nie przypuszczał, że niektórzy z jego podwładnych będą oferowali im alkohol i prowokowali do tragicznych w skutkach walk ${ }^{42}$. Alkohol przywieziony przez białych ludzi z Europy stał się dla Aborygenów czynnikiem niszczycielskim, a piętno tego uzależnienia widoczne jest do dzisiaj.

Przed najazdem Brytyjczyków tubylcy sporządzali napoje niskoalkoholowe, delikatne, głównie z roślin zielonych i owoców. Ich wykorzystywanie było ściśle kontrolowane. Służyły lekkiemu odurzeniu, aby wzmocnić kontakt z bóstwami podczas uroczystości plemiennych. Trunki takie mogli spożywać jedynie przedstawiciele senatów plemiennych (starszyzny). W niedługim czasie po dokonaniu inwazji na ląd australijski alkohol stał się produktem najbardziej pożądanym i o wysokiej wartości. Kupowanie i spożywanie rumu było bardzo rozpowszechnione. Rum i nikotyna stały się podstawowym środkiem płatniczym wśród pracowników pochodzenia aborygeńskiego. Brytyjscy żołnierze szybko zorientowali się, że Aborygeni, których organizmy źle radzą sobie z alkoholem, niezwykle szybko się od niego uzależniają. Tubylcy sądzili, że spożywanie alkoholu jest sposobem na akceptację w środowisku białych. Regularnymi praktykami stało się płacenie alkoholem za seks z aborygeńskimi kobietami, upijanie tubylców do

42 M. Clark, op.cit., s. 58. 
nieprzytomności, a także w wielu przypadkach organizowanie zawodów i walk toczonych aż do śmierci.

Dzisiaj w Australii mówi się o „epidemii picia”.Z wyników National Aboriginal and Torres Strait Islander Health Survey z lat 2004-2005 roku można wywnioskować, że problem alkoholowy jest w tej społeczności głęboko zakorzeniony i niezwykle poważny. W dokumencie tym czytamy, że połowa badanych Aborygenów spożywała alkohol w tygodniu poprzedzającym udzielenie wywiadu. Przy czym co trzeci badany przyznał, że spożywał alkohol w stopniu znacznym. Jest to wskaźnik wyższy niż odnotowany 3 lata wcześniej ${ }^{43}$. Warto podkreślić jednak, że funkcjonują w Australii rezerwaty, w których obowiązuje całkowity zakaz spożywania napojów alkoholowych. Ci, którzy prawo to łamią, są z rezerwatu wypędzani. Wówczas przybywają do miast i tam funkcjonują jako pijani i awanturujący się bezdomni. Prawie połowa aborygeńskich matek piła w czasie ciąży ${ }^{44}$. Nietrudno się domyślić, że alkohol jest przyczyną wielu problemów społecznych. Wśród najważniejszych wymienić można przemoc w rodzinie i doprowadzenie do jej rozpadu, utratę dochodów, zaniedbywanie, a w skrajnych przypadkach molestowanie seksualne i gwałcenie dzieci, a także zabójstwa i samobójstwa. Niezwykle często całe zapomogi przeznaczane są na alkohol i narkotyki, które przemycane są nocą do aborygeńskich obozowisk przez białych. Degradacja społeczna i demoralizacja przenoszą się również na stan domostw i osiedli.

Jak wspomniano, dzisiaj Aborygeni mieszkają przede wszystkim w rezerwatach, misjach i osiedlach dla tubylców. Pierwszy rezerwat powstał jeszcze za czasów kolonialnych. Jego celem nie była jednak izolacja, ale opieka nad miejscowymi i zabezpieczenie przez agresją białych. Miejscami takimi opiekowali się najczęściej misjonarze ewangeliccy. Dzisiaj rezerwaty są zwykle ośrodkami degradacji i zacofania. Aborygeni mieszkają w domach, których standard jest bardzo niski. Bywa, że brakuje w nich wody i elektryczności. Niektórzy z domów wcale nie korzystają - wolą spać w zbudowanych z kartonu, desek i blach szałasach. W 2007 roku rząd przekazał 7 mln dolarów na renowację i budowę nowych domów - jednak i ten program nie spotkał się z przychylnością tubylców ${ }^{45}$.

43 National Aboriginal and Torres Strait Islander Health Survey z lat 2004-2005, Australia Bureau of Statistics, http://www.abs.gov.au/ausstats/abs@.nsf/mf/4715.0/, odczyt z dn. 10.02.2014.

44 Aboriginal Alcohol Consumption, http://www.creativespirits.info/aboriginalculture/health/ aboriginal-alcohol-consumption.html, odczyt z dn. 10.02.2014.

45 M. Szaniewski, Aborygeni chca być uchodźcami w Australii, „Gazeta Wyborcza”, 28.08.2009, http://wyborcza.pl/1,76842,6972815,Aborygeni_chca_byc_uchodzcami_w_Australii.html\#ixzzluw My20JF, odczyt z dn. 18.02.2011. 
Budynki znajdujące się na terenach rezerwatów, takie jak szkoła czy sklep, są zdewastowane i regularnie trzeba je odnawiać.

Native Title Act z 1993 roku spowodował, że Aborygeni masowo zaczęli upominać się o swoje ziemie. Nie tylko jednak te związane $\mathrm{z}$ dawnymi wierzeniami - jak święta góra Uluru w centralnej Australii. Gdy dostrzeżono, że na dawnych terytoriach plemiennych największe australijskie, amerykańskie i chińskie koncerny otwierają swoje bazy wydobywcze, roszczenia wobec uzyskania praw do tych ziem nasiliły się. Gdzieniegdzie już w latach 80 . podpisano porozumienia między radami osiedli tubylczych a koncernami. Na wyspie Groote Eylandt koncern Broken Hill zobowiązał się w umowie do zapłacenia tubylcom 10 tysięcy dolarów za wydobycie pierwszych 100 tysięcy ton boksytu oraz do regularnego przekazywania kolejnych $2 \% \mathrm{z}$ wartości wydobycia ${ }^{46}$. Nie wszędzie jednak takie porozumienia udało się osiągnąć. Wiadomo też, że przekazywane pieniądze nie zawsze przeznaczane są na polepszanie warunków ekonomicznych i społecznych klanów oraz rozwój rezerwatów, często wydawane są na używki. Przykład walki o ziemię pokazuje jednak dwie ważne sprawy. Po pierwsze, Aborygeni zaczęli upominać się i walczyć o to, co do nich należało, oraz próbują rekompensować krzywdy, których doznali ich przodkowie, a po drugie, jeśli w grę wchodzi niemały zysk, to nawet cywilizacja białych na terenach tubylczych jest akceptowana. Ziemia, która niegdyś była wspólna i nie należała do nikogo, dzisiaj ma powrócić do pierwotnych „właścicieli”.

Zdecydowana większość Aborygenów trwa w epoce zatracenia. Choć rząd australijski od kilkudziesięciu lat stara się naprawić wyrządzone krzywdy, zmienia prawo, nadaje kolejne przywileje, oddaje ziemie lub dzieli się zyskami z wydobycia surowców naturalnych, to realne efekty tych działań są niewielkie. I to nie ze względu na to, że owa polityka jest nieprzemyślana czy słaba. Ze względu na fakt, że sami Aborygeni nie chcą z tych udogodnień korzystać. Rezerwaty stworzone dla ochrony ludności tubylczej stały się gettami biedy i zacofania. Każdego roku rząd wydaje miliony dolarów na usuwanie szkód i naprawę zdewastowanych osiedli. Jednak Aborygenom nie została przydzielona żadna rola w nowoczesnym kapitalistycznym społeczeństwie i być może to właśnie stanowi zarzewie kolejnych problemów i konfliktów. Sami tubylcy też nie potrafią odnaleźć się w tej rzeczywistości. Raczej walczą ze światem, niż próbują wykorzystać jego zasoby. Tworzenie przez dziesiątki lat białej cywilizacji na Antypodach nie sprzyjało integracji. W latach 70. Adam Paluch twierdził,

46 P. Burchard, op.cit., s. 132. 
że przeobrażenia i procesy akulturacyjne doprowadzą do zupełnej asymilacji ludności czarnoskórej z białymi, a rodzima kultura zaniknie ${ }^{47}$. Stało się jednak odwrotnie. Aborygeni, nadal wyizolowani ze społeczeństwa i nieprzystosowani do życia w cywilizacji, dbają jednak o rozwój kultury rodzimej. To jedyna rzecz, która pozostała z czasów ich przodków i jedna z niewielu, za którą zostają docenieni na świecie. Tubylcy, którzy „mieli zostać nauczeni myśleć tak, jak my myślimy, czuć jak my, żyć jak my"48, nie poddali się tej edukacji i nie chcieli wtopić się w społeczeństwo anglosaskie, a dzisiaj już wielokulturowe. Wydaje się, że obrali właśnie taki sposób na zaznaczenie swej tożsamości i indywidualizmu.

Choć od czasów kolonizacji brytyjskiej minęło już ponad 200 lat, to w świadomości wielu Aborygenów niewiele się zmieniło. Woli do takowych zmian potrzeba jednak z obu stron. Wydaje się, że po stronie rządu australijskiego wola taka jest. We wszystkich raportach rządowych oraz organizacji non-profit podkreśla się znaczenie potrzeby radykalnego porzucenia stereotypowania tubylców. Zwraca się uwagę z jednej strony na szczególne traktowanie czarnoskórych mieszkańców, a z drugiej strony na uznanie i poszanowanie ich „normalnej” egzystencji. Co rusz słyszymy o specjalnych projektach ochrony (które nie tylko są ogłaszane, ale i realizowane). Dotyczą nie tylko kwestii zdrowotnych, ale i mieszkaniowych oraz zatrudnienia. Brakuje jednak woli w społeczeństwie australijskim - w samym tylko słowniku Assie Language znajduje się kilkadziesiąt obraźliwych zwrotów określających Aborygenów. Trudno dostrzec też taką wolę integracji i współpracy wśród tych, którzy siedzą na chodnikach, są agresywni wobec przechodniów i nie podejmują się (z założenia) żadnej pracy zarobkowej. Wydaje się, że powoli kończy się więc lista pomysłów i środków na ratowanie sytuacji.

Złego położenia Aborygenów nie można oczywiście generalizować i przekładać na wszystkie plemiona. Znajdziemy wielu potomków dawnych klanów, którzy pracują, zarabiają, utrzymują siebie i swoje rodziny - żyją na dobrym poziomie. Znajdziemy też takich, którzy wywodzą się ze społeczności aborygeńskiej (Noel Pearson, David Gulpilil, Cathy Freeman, Jessica Mauboy) i działają na rzecz potomków pierwotnych mieszkańców i, którzy stali się symbolami, swoistym pomostem pomiędzy kulturą i tożsamością swoich przodków a „cywilizacją białych".

\footnotetext{
47 A. Paluch, Obszary kulturowe Pacyfiku, Wrocław 1979, s. 16.

48 M. Clark, op.cit., s. 60.
} 